\title{
Nutrient potential of watermelon (Citrullus lanatus) seeds and its incorporation in product preparation
}

\author{
JYOTI TAK AND SHASHI JAIN
}

\begin{abstract}
The water melon seeds were analyzed for its different properties such as the physico-chemical and functional properties and nutritional properties. The seeds were also incorporated in products to assess the acceptability. Watermelon seeds have been protected with hard cover which is to be removed for the use of seeds in products. The water melon seed revealed as light cream in colour and oval in shape. The average seed length was $8.01 \pm 1.02(\mathrm{~mm})$ and weight was $0.82 \pm 0.1(\mathrm{~g})$ and volume $3.42(\mathrm{ml})$, respectively. Water absorption capacity $(\%)$ found $116.3 \pm 0.1$ and the least gelatinization capacity was $29.7 \pm 0.2$. The result of proximate composition of watermelon seeds reveals that moisture content of seed was low $4.9 \mathrm{~g}$, ash content of the seeds was $2.9 \mathrm{~g}$, fat content was good which was $48.9 \mathrm{~g}$, protein content was $32.6 \mathrm{~g}$ and energy value was high $619 \mathrm{kcal}$ per $100 \mathrm{~g}$. The powder was incorporated in recipes at 5 per cent, 8 per cent and 10 per cent. The overall acceptability scores of developed product ranged from 6.7 to 7.4 on 9 point hedonic scale. The results of proximate analysis indicated that watermelon seeds had the higher value of protein, fat, ash, oil and fibre contents. It is concluded that water melon seeds flour can be successfully incorporated in vegetable gravy.
\end{abstract}

Key Words : Water melon seeds, Analysis, Nutritional properties, Product preparation

How to cite this article : Tak, Jyoti and Jain, Shashi (2016). Nutrient potential of watermelon (Citrullus lanatus) seeds and its incorporation in product preparation. Food Sci. Res. J., 7(2): 202-206, DOI : 10.15740/HAS/FSRJ/7.2/202-206. 